\section{Summary points}

Urinary tract infections are the second most common infections, after respiratory infections, resulting in considerable anxiety and morbidity in women

Underlying anatomical abnormalities in women with recurrent lower urinary tract infections are uncommon, and further investigations such as imaging studies are rarely warranted

In women with three or more urinary tract infections a year, consider preventive medication

In postmenopausal women, topical vaginal oestrogen cream decreases the risk of recurrent urinary tract infections. ${ }^{19 \mathrm{w} 33}$

In women who have three or more urinary tract infections a year consider ${ }^{20}$ :

- Patient initiated short course of antibiotic therapy at the onset of symptoms suggesting cystitis ${ }^{8}$

- Post-coital prophylaxis (single dose of trimethoprim $200 \mathrm{mg}$, nitrofurantoin, or a quinolone) if cystitis has been related to sexual intercourse

- Continuous daily or thrice weekly prophylaxis for a longer period (six months or more).

Prophylaxis should be started after active infection has been eradicated (confirmed by a negative urine culture at least one to two weeks after treatment is stopped). ${ }^{\mathrm{w} 5}$ Prophylaxis does not make recurrent urinary tract infections less likely to recur. When prophylaxis is discontinued, even after having been taken for extended periods, more than $50 \%$ of women will have another infection within three months.

\section{Follow-up}

Routine follow-up is not needed for lower urinary tract infections but is recommended for upper urinary tract infections after the treatment is completed.

Management of urinary tract infections in pregnancy requires proper diagnostic workup and thorough understanding of antimicrobial agents to optimise maternal outcome, ensure safety to the fetus, and prevent complications in both the fetus and the mother.

Competing interests: None declared.

1 Malterud K, Baerheim A. Peeing barbed wire. Symptom experiences in women with lower urinary tract infection. Scand J Prim Health Care 1999;17:49-53.

2 Foxman B, Barlow R, D'Arcy H, Gillespie B, Sobel JD. Urinary tract infection: self-reported incidence and associated costs. Ann Epidemiol 2000;10:509-15.

3 Hooton TM, Scholes D, Hughes JP, Winter C, Roberts PL, Stapleton AE, et al. A prospective study of risk factors for symptomatic urinary tract infection in young women. N Engl J Med 1996;335:468-74.

4 Stamm WE, Hooton TM. Management of urinary tract infections in Stamm WE, Hooton TM. Management
adults. N Engl J Med 1993;329:1328-34.

5 Bent S, Nallamothu BK, Simel DL, Fihn SD, Saint S. Does this woman Bent S, Nallamothu BK, Simel DL, Finn SD, Saint S. Does this woman
have an acute uncomplicated urinary tract infection? JAMA 2002;287:2701-10

6 Barry HC, Hickner J, Ebell MH, Ettenhofer T. A randomized controlled trial of telephone management of suspected urinary tract infections in women. J Fam Pract 2001;50:589-94.

7 Wong ES, McKevitt M, Running K, Counts GW, Turck M, Stamm WE. Management of recurrent urinary tract infections with patientadministered single-dose therapy. Ann Intern Med 1985;102:302-7.

8 Gupta K, Hooton TM, Roberts PL, Stamm WE. Patient-initiated treatment of uncomplicated recurrent urinary tract infections in young treatment of uncomplicated recurrent
women. Ann Intern Med 2001;135:9-16.

9 Bent S, Saint S. The optimal use of diagnostic testing in women with Bent S, Saint S. The optimal use of diagnostic testing in wor
acute uncomplicated cystitis. Am J Med 2002;113(Suppl 1):20-8.

10 Medina-Bombardo D, Segui-Diaz M, Roca-Fusalba C, Llobera J. What is the predictive value of urinary symptoms for diagnosing urinary tract infection in women? Fam Pract 2003;20:103-7.

11 Fahey T, Webb E, Montgomery AA, Heyderman RS. Clinical management of urinary tract infection in women: a prospective cohort study. Fam Pract 2003;20:1-6.

12 Lifshitz E, Kramer L. Outpatient urine culture: does collection technique matter? Arch Intern Med 2000;160:2537-40.

13 Hanno PM. The diagnosis of interstitial cystitis revisited: lessons learned from the National Institutes of Health interstitial cystitis database study. $J$ from the National Ins

14 Strom BL, Collins M, West SL, Kreisberg J, Weller S. Sexual activity, contraceptive use, and other risk factors for symptomatic and asymptomatic bacteriuria. A case-control study. Ann Intern Med 1987;107:816-23.

15 Warren JW, Abrutyn E, Hebel JR, Johnson JR, Schaeffer AJ, Stamm WE. Guidelines for antimicrobial treatment of uncomplicated acute bacterial cystitis and acute pyelonephritis in women. Infectious Diseases Society of America (IDSA). Clin Infect Dis 1999;29:745-58.

16 Davey P, Steinke D, MacDonald T, Phillips G, Sullivan F. Not so simple cystitis: how should prescribers be supported to make informed decisions about the increasing prevalence of infections caused by drug-resistant bacteria? Br J Gen Pract 2000;50:143-6.

17 Vogel T, Verreault R, Gourdeau M, Morin M, Grenier-Gosselin L, Rochette L. Optimal duration of antibiotic therapy for uncomplicated urinary tract infection in older women: a double-blind randomized controlled trial. CMAJ 2004;170:469-73.

18 MacLean AB. Urinary tract infection in pregnancy. Int J Antimicrob Agents 2001;17:273-7.

19 Raz R, Stamm WE. A controlled trial of intravaginal estriol in postmenopausal women with recurrent urinary tract infections. $N$ Engl J Med 1993;329:753-6.

$20 \mathrm{Car}$ J, Sheikh A. Recurrent urinary tract infection in women. BMJ 2003;327:1204.

\title{
Primum non nocere
}

I was sitting in the outpatients clinic of the cardiology department the other day. A little boy in a wheelchair came in with his father. His father was greeted by the receptionist and whisked off for echocardiography. The little boy stayed in the waiting room and cruised around skilfully in his wheelchair. He had both legs partly encased in plaster with a metal bar between the two holding his legs in a fixed position.

Pictures of the heart decorated the walls of the waiting room; some were medical images generated from angiograms, but others were far more weird and wonderful, including wood, glass, and metal creations. The little boy was transfixed by them. I struck up a conversation with him about his legs and the content of the pictures. He was very enthusiastic and curious. Just before he left with his father I asked him if he wanted to be a doctor. His response surprised me. "No," he replied forcefully, "I don't want to hurt people."
Of course, he was right. Doctors are traditionally thought of as healers, but I have been surprised on my journey so far through medicine by how much of our time is spent inflicting pain on others with the intention of helping them in the end.

Laura Wilkins medical student, Green College, at the Radcliffe Observatory, Oxford (laura.wilkins@medschool.ox.ac.uk)

We welcome articles up to 600 words on topics such as A memorable patient, A paper that changed my practice, My most unfortunate mistake, or any other piece conveying instruction, pathos, or humour. Please submit the article on http:// submit.bmj.com Permission is needed from the patient or a relative if an identifiable patient is referred to. We also welcome contributions for "Endpieces," consisting of quotations of up to 80 words (but most are considerably shorter) from any source, ancient or modern, which have appealed to the reader. 